\title{
Report to Congress on Reassessment of the Civilian Radioactive Waste Management Program
}

\section{November 1989}

U.S. Department of Energy

Office of Civilian Radioactive Waste Management

Washington, DC 20585 



\section{DISCLAIMER}

This report was prepared as an account of work sponsored by an agency of the United States Government. Neither the United States Government nor any agency thereof, nor any of their employees, make any warranty, express or implied, or assumes any legal liability or responsibility for the accuracy, completeness, or usefuiness of any information, apparatus, product, or process disclosed, or represents that its use would not infringe privately owned rights. Reference herein to any specific commercial product, process, or service by trade name, trademark, manufacturer, or otherwise does not necessarily constitute or imply its endorsement, recommendation, or favoring by the United States Government or any agency thereof. The views and opinions of authors expressed herein do not necessarily state or reflect those of the United States Government or any agency thereof. 


\section{DISCLAIMER}

Portions of this document may be illegible in electronic image products. Images are produced from the best available original document. 
REASSESSMENT OF THE CIVILIAN RADIOACTIVE WASTE MANAGEMENT PROGRAM

Report to the Congress by the Secretary of Energy

November 29, 1989 


\section{FOREWORD}

In the Report of the House Committee on Appropriations (House Report No. 101-96) on the Energy and Water Development Appropriation Act, 1990 (P.L. 101101), the Committee directed the Department of Energy (DOE) ". . . to submit a report within 60 days of enactment ... which describes in detail how the Department plans to respond to the Committee's ... concerns dealing with endemic schedule slips, problems in management structure, and lack of integrated contractor efforts."

This report has been prepared in response to the above-mentioned Congressional directive. It is based on a comprehensive review that the Secretary of Energy has recently completed of the Civilian Radioactive Waste Management Program. The Secretary's review has led to the development of a three-point action plan for restructuring the program. This plan is explained in this report. 


\section{TABLE OF CONTENTS}

Page

EXECUTIVE SUMMARY $\ldots \ldots \ldots \ldots \ldots \ldots \ldots \ldots \ldots \ldots$ vii

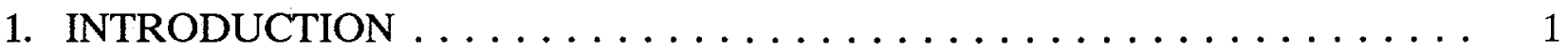

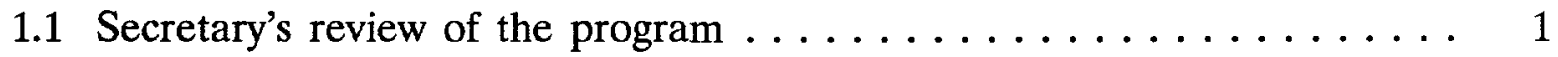

1.2 The need for a restructured program $\ldots \ldots \ldots \ldots \ldots \ldots \ldots \ldots \ldots \ldots \ldots \ldots$

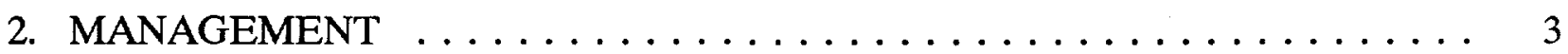

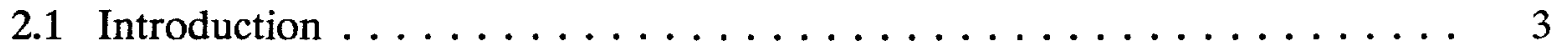

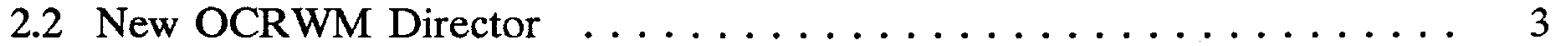

2.3 Direct-line reporting $\ldots \ldots \ldots \ldots \ldots \ldots \ldots \ldots \ldots \ldots \ldots$

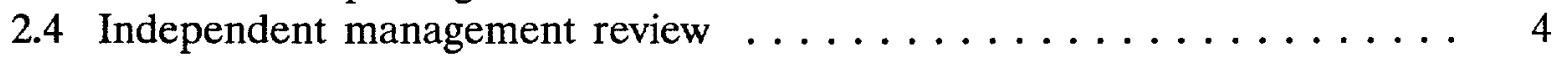

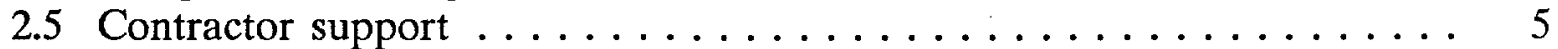

2.6 Management-system improvements $\ldots \ldots \ldots \ldots \ldots \ldots$

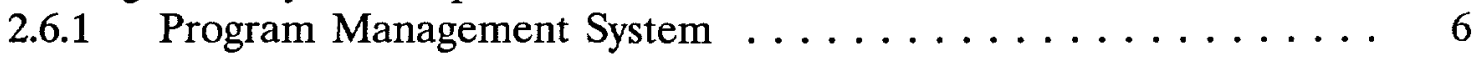

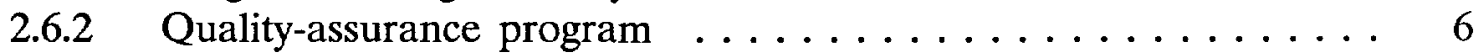

2.6.3 Establishment of baselines . . . . . . . . . . . . . 7

2.7 Development of a realistic schedule $\ldots \ldots \ldots \ldots \ldots \ldots$

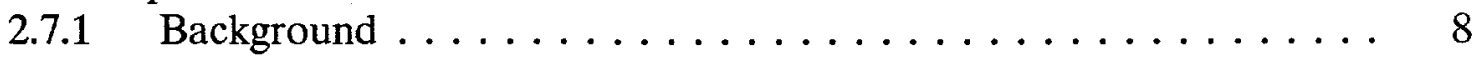

2.7.2 Schedule changes stemming from the Secretary's comprehensive

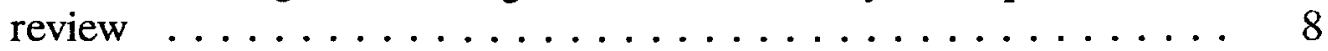

2.8 Nuclear Waste Negotiator ... . . . . . . . . . . . . . 12

3. SCIENTIFIC INVESTIGATION OF YUCCA MOUNTAIN . . . . . . . . . 13

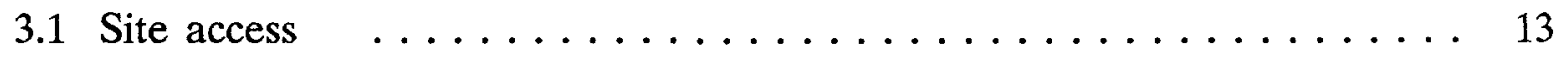

3.2 Early evaluation of site suitability $\ldots \ldots \ldots \ldots \ldots \ldots \ldots$

3.3 Deferral of major site-specific design activities $\ldots \ldots \ldots \ldots$

4. MONITORED RETRIEVABLE STORAGE $\ldots \ldots \ldots \ldots \ldots \ldots$

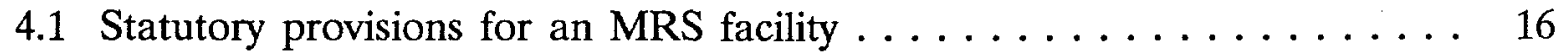

4.2 MRS Review Commission . . . . . . . . . . . . . . . . . . . 16

4.3 DOE's position on the MRS facility $\ldots \ldots \ldots \ldots \ldots \ldots \ldots$

4.4 DOE's initiatives for the MRS facility $\ldots \ldots \ldots \ldots \ldots \ldots$

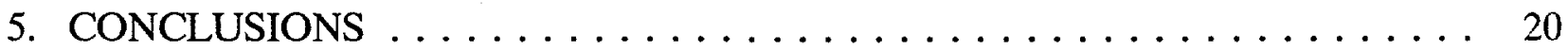

ACRONYMS AND ABBREVIATIONS USED IN ATTACHMENTS . . . . . . 21 


\section{LIST OF FIGURES AND ATTACHMENTS}

$\underline{\text { Page }}$

Figure 1: Reference schedule for restructured program $\ldots \ldots \ldots \ldots \ldots \ldots$

Attachment 1: Scientific Investigation Plan: Schedule Through Repository License Application

Attachment 2: Scientific Investigation Plan: Near-Term Decision Plan 


\section{EXECUTIVE SUMMARY}

The success of the Civilian Radioactive Waste Management Program of the U.S. Department of Energy (DOE) is critical to U.S. ability to manage and dispose of nuclear waste safely--and to the reestablishment of confidence in the nuclear energy option in the United States. The program must conform with all applicable standards and, in fact, set the example for a national policy on the safe disposal of radioactive waste.

The Secretary of Energy has recently completed an extensive review of the Civilian Radioactive Waste Management Program and concluded that it cannot be effectively executed in its current form. In response to Congressional concerns about schedule slips, management structure, and contractor efforts in the program, this report describes the results of that review and outlines actions the Secretary has taken and will take in the near future to restructure the program in order to get it moving forward again.

An important underlying premise of these Secretarial actions is that the program and supporting activities have a sound scientific basis. The intent is to develop and follow a solid, integrated plan based on a realistic assessment of the current situation.

Several months ago, the Secretary directed that a comprehensive review of the schedule for repository-related activities be performed. For the first time since the passage of the Nuclear Waste Policy Act, the program has put together a schedule based on a realistic assessment of activity durations and past experience. This schedule shows a significant slip for the expected start of repository operations--from the year 2003 to approximately 2010 . In developing the revised schedule, the DOE was mindful that certain activities, such as the issuance of environmental permits by the State of Nevada and the Nuclear Regulatory Commission review of the license application, are outside the DOE's control.

One new emphasis of the program's efforts will be on completing an integrated array of near-term milestones directed at the scientific investigation of the potential site at Yucca Mountain in Nevada. Since a licensed geologic repository is a first-of-a-kind undertaking, the later dates in the schedule should be viewed as reasonable targets that represent the current estimate of activity durations. The DOE, however, pledges its best efforts toward meeting the near-term and later milestones consistent with its goals of safety and scientific excellence.

To promote the DOE's ability to achieve such milestones and goals, the Secretary is announcing the initiation of a three-point action plan. This plan centers on a 
restructuring of the Office of Civilian Radioactive Waste Management, initiatives to gain access to the Yucca Mountain site to continue the scientific investigations needed to evaluate the site's suitability for a repository, and an initiative for establishing integrated monitored retrievable storage (MRS) with a target for spent-fuel acceptance in 1998. The major elements of this plan are outlined below.

\section{Management structure}

1. Appointment of new Director: The Secretary has proposed a candidate for a new Director of the Office of Civilian Radioactive Waste Management to the White House for appointment by the President. The program has been managed by acting Directors for over two years. The new Director will have the freedom to propose program changes in addition to those discussed in this report.

2. Direct-line reporting: Direct-line reporting by the Manager of the Yucca Mountain Project to the Office of Civilian Waste Management at Headquarters has been established. This allows for a direct line of authority and accountability between the Headquarters and field elements of the program for the first time.

3. Independent management review: The Secretary has directed that an independent review be performed to assess the effectiveness of the program organizational structure and processes. The review will include an examination of management structure and systems. The results of this review will be incorporated into the program restructuring beginning in January 1990.

4. Contractor support: Several reviews have been initiated to examine the program's current use of contractors to streamline and, where possible, consolidate contracts. In some areas, the number of contractors has already been reduced. As a result of schedule adjustments, some contractor work will be deferred, while other work may be accelerated. Because of uncertainties resulting from the revised program focus, there is a need to reassess options for contractor support. This is expected to be completed in the next few months.

5. Management controls: Formal, more rigorous program and project management controls are being implemented to enhance those previously in place. This includes the development or revision of technical, schedule, and cost baselines subject to formal change-control procedures.

6. Nuclear Waste Negotiator: The Secretary is working in close cooperation with the White House to facilitate the appointment of the Nuclear Waste Negotiator as provided for in the Nuclear Waste Policy Amendments Act. The Negotiator could provide valuable assistance in promoting progress in the repository and MRS programs. 


\section{$\underline{\text { Yucca Mountain }}$}

1. Site access: An important prerequisite to new scientific investigations at Yucca Mountain is issuance of the required environmental permits by the State of Nevada. The DOE has attempted to work constructively and positively with the State over the past years, but the State government has been adamantly opposed to the program and has failed to provide environmental permits. While continuing efforts to resolve the current permitting impasse through direct negotiations, the DOE has requested the Department of Justice to initiate litigation to obtain the necessary permits.

2. Site suitability: The priority of the site-characterization activities at Yucca Mountain will be on scientific investigations of the suitability of the site. The DOE plans to take advantage of some early surface-based tests in advance of the ability to construct the exploratory shaft facility. The DOE continues to believe that an iterative scientific approach using both surface-based and underground tests, combined with continuing evaluation of the data as they relate to site suitability, is the efficient, cost-effective, and timely way to conduct the scientific investigations. The early emphasis on surface-based tests to examine the suitability of the site is responsive to suggestions from the State of Nevada and the Edison Electric Institute. The DOE is also carefully reviewing suggestions from the Nuclear Waste Technical Review Board and the Nuclear Regulatory Commission on the design of the exploratory-shaft facility prior to the beginning of major underground investigations. It should be noted that, if the site is found unsuitable at any time during characterization, the DOE will notify the State of Nevada and the Congress and will discontinue further scientific evaluation at Yucca Mountain.

3. Deferral of major site-specific design activities: Major activities related to the design of a repository at the Yucca Mountain site will be deferred until more information is available concerning the suitability of the site. This will conserve resources and allow the concentration of efforts on the scientific investigations.

\section{$\underline{\text { Monitored retrievable storage }}$}

1. Linkages to the repository: The primary objective of the program is to develop a licensed geologic repository for the permanent disposal of spent fuel and highlevel waste. The DOE has an obligation to accept spent fuel from the utilities in accordance with the Standard Contract for Disposal of Spent Nuclear Fuel/and or High-Level Radioactive Waste and the Nuclear Waste Policy Act as amended. However, a detailed examination of the repository schedule, allowing the time necessury for sound scientific investigation and design, shows that the DOE cannot 
meet the anticipated schedule set forth in the Act for the disposal of waste in a repository by 1998; furthermore, the current linkages between the repository and the MRS program make it impossible for the DOE to accept waste at an MRS facility on a schedule that is independent from that of the repository. Therefore, the DOE plans to work with the Congress to modify the current linkages between the repository and the MRS facility and to embark on an aggressive program to develop an integrated MRS facility for spent fuel. The DOE believes that if the linkages are modified, it is likely that waste acceptance at an MRS facility could begin by 1998 or soon thereafter.

2. Options for monitored retrievable storage: The DOE is also continuing to study a variety of options to the Monitored Retrievable Storage facility to offer the utilities a predictable and reliable plan for waste acceptance. The recommendations of the MRS Review Commission are being considered fully in the development of these options. 


\section{INTRODUCTION}

\subsection{Secretary's review of the program}

The Secretary of Energy has recently completed an extensive review of the Civilian Radioactive Waste Management Program and has concluded that the program cannot be effectively executed in its present form. From this review it was apparent that the causes of delays are twofold. First, there are delays that result from extending the durations of site-characterization and repository-development activities. These delays are attributable to (1) underestimation by the DOE of the impact of regulatory requirements for quality assurance and design control on a repository schedule that was unrealistically ambitious and (2) the misperception that the program is simply a construction project rather than a first-of-its-kind scientific investigation. Second, there are critical delays in the start of new scientific investigations at the Yucca Mountain candidate site--delays attributable, in part, to an unwillingness on the part of the State of Nevada to allow the scientific investigations that are necessary to determine the suitability of the Yucca Mountain site.

The Secretary recognizes that the program is technically and institutionally unprecedented. In order to obtain a license for the repository, the DOE will have to design and implement an iterative program of scientific investigations, engineeredbarrier designs, and performance assessments that will permit a determination whether the repository system--both the natural features of the site and the engineered barriers-will meet the standards promulgated by the Environmental Protection Agency and the technical criteria issued by the Nuclear Regulatory Commission (NRC) to implement those standards. The Secretary also recognizes that the program is not simply a construction project, but a scientific endeavor of critical significance to the Nation's ability to safely manage and dispose of nuclear waste, and to the reestablishment of confidence in the nuclear energy option in the United States. It is also important that the program provide a model for other nations as they work to meet their energy needs and solve their radioactive-waste-disposal problems. Consequently, the Secretary is committed to ensuring that scientific investigations be the focal point of the program to ensure that the results are technically sound and uncoupled from a scheduling process that constrains the time required for gathering sufficient information. 


\subsection{The need for a restructured program}

The new emphasis of the program will be on completing an integrated array of near-term milestones directed at the scientific investigation of the Yucca Mountain site to determine the suitability of this site for a repository.

As a result of his review and in response to Congressional concerns, the Secretary has initiated a management action plan that contains three major elements:

- Developing and implementing a new management structure.

- Gaining access to the Yucca Mountain candidate site and initiating comprehensive scientific investigations as the focus of site characterization.

- Developing options for ensuring the timely acceptance of spent fuel through the establishment of monitored retrievable storage (MRS).

The principal elements of this management action plan are outlined in this report. A detailed discussion of the plan as it will be implemented will be presented in a revised Mission Plan for the Civilian Radioactive Waste Management Program. A draft of this document will be issued for public review and comment by June 1990 .

The Secretary considers that this action plan responds to the concerns of the Congress, will help regain public confidence, and will enable the Federal Government to meet its obligations to the Nation to safely dispose of spent fuel and high-level waste in accordance with the following general goals:

- Protecting public health and safety and the quality of the environment in the management and disposal of spent fuel and highlevel waste.

- Developing an NRC-licensed geologic repository for the permanent disposal of spent fuel and high-level waste.

- Beginning the operation of the waste-management system as soon as practicable in order to be able to accept spent fuel and high-level waste for disposal at a significant rate during the early years of operation.

- Establishing public confidence that the management of radioactive waste is not an obstacle to the nuclear energy option. 


\section{MANAGEMENT}

\subsection{Introduction}

To manage the program mandated by the Nuclear Waste Policy Act, the Congress established, within the DOE, the Office of Civilian Radioactive Waste Management (OCRWM), whose Director is to be appointed by the President, by and with the advice and consent of the Senate.

The program has unique characteristics that affect its management structure, including the following:

- Requirements to obtain licenses from the Nuclear Regulatory Commission and to maintain a quality-assurance program that is acceptable to the Commission.

- Requirements to interface with Congressionally mandated technical review boards, offices, and commissions.

- Geoscience and performance-assessment capabilities necessary to meet the EPA and NRC requirements for the repository.

- Institutional issues involved in dealing with the affected States, local governments, Indian Tribes, and the public.

- Maintaining contractual relationships with the utilities.

- Responsibilities associated with the investment and management of the Nuclear Waste Fund.

As discussed below, steps have already been taken to establish an improved management structure and procedures.

\subsection{New OCRWM Director}

The Director of the OCRWM is responsible for carrying out the functions assigned to the Secretary of Energy under the Nuclear Waste Policy Act, as amended. The OCRWM has been headed by acting directors for the past 2 years. The appointment of an OCRWM Director is necessary not only for the management and direction of the program but also to expedite the initiatives resulting from the Secretary's review of the program. 
The Secretary has chosen a candidate for the OCRWM Director and has submitted his nomination to the White House. It is expected that the nomination will be submitted to the Senate for confirmation when the Congress reconvenes in January 1990.

\subsection{Direct-line reporting}

The DOE has recently established direct-line reporting from Operations Offices to Headquarters to facilitate the management and execution of certain major programs. Under the previous management structure, multiple lines of authority existed. Projectoffice managers and Operations Office managers received program policy guidance and technical direction from Headquarters program offices, such as the OCRWM; however, project managers reported administratively to their respective Operations Office managers, who reported to the Under Secretary. Direct reporting will bring together authority and responsibility and facilitate coordination and communication.

In accordance with this new management approach, a direct line of authority and responsibility has been instituted for the Yucca Mountain Project. As a result, the Yucca Mountain Project Office reports directly to the OCRWM for all programmatic and policy direction and is accountable for implementing that direction.

\subsection{Independent management review}

At the direction of the Secretary, an independent assessment of OCRWM management is under way. It is being conducted by a private corporation that is well known for its expertise in management consulting and is not directly or indirectly involved in the program. Considering the unique characteristics of the program, as outlined in the introduction to this report, this assessment is examining management structures, systems, and procedures, and its main purpose is to identify redundancies, gaps, and strengths. Once the review of existing systems and procedures has been completed, the DOE expects to receive recommendations on improvements to the existing arrangements and alternative structures or processes that would enhance the management of the program. Final recommendations will be available in January 1990. 


\subsection{Contractor support}

Like many Federal agencies, the OCRWM relies on contractors to provide the services needed to carry out its technical functions. The functions that are performed by the OCRWM and the DOE Project Offices are the management functions that involve the exercise of discretionary authority, the development and implementation of policy, decisionmaking, and final value judgments regarding the development, execution, and evaluation of the program.

Examples of the services performed by OCRWM contractors are design and engineering; geologic, hydrologic, and geochemical investigations; the development and implementation of methods and techniques for assessing the safety and performance of the repository and other waste-management facilities; and facility construction, operation, maintenance, and testing. In addition, the OCRWM contracts for outside expertise, beyond that available within the organization itself, to support or improve program analysis, decisionmaking, management, and administration and to support or improve the operation of management systems. These various services are being provided by a variety of contractors, including the national laboratories.

Changes in the program, discussed in the next section, are expected to reduce near-term needs for contractor support in a variety of areas, such as the design of the exploratory-shaft facility needed for scientific investigations at Yucca Mountain, the designs of the repository and the waste package, and some field studies. In keeping with its general approach of adjusting contractor support to a level consistent with the schedule and available funding, the OCRWM initiated a review of its contracted work to identify the activities that could be deferred, canceled, or consolidated. The OCRWM is now analyzing the results to determine specific actions that could be taken to enhance cost effectiveness, integrate activities, and improve management oversight.

The contract review has prompted the following actions:

1. The number of contractors involved in performance assessment for the repository has been reduced from thirteen to eight.

2. A significant portion of the waste-package work previously assigned to the Chicago Operations Office has been transferred to, and consolidated with, waste-package work at the Yucca Mountain Project Office.

3. The geophysics and geohydrology research previously assigned to the Chicago Operations Office has been transferred to the Yucca Mountain Project Office. 
Moreover, reductions in the funds appropriated by the Congress for fiscal year 1990 have already prompted reductions in the scope of contractor work in several other areas.

In an effort to enhance the integration of contractor activities and products, the OCRWM had planned to hire a management-and-operating (M\&O) contractor. In 1988, after issuing a request for proposals and receiving three proposals, the DOE selected the $\mathrm{M} \& \mathrm{O}$ contractor, but one of the unsuccessful bidders subsequently filed suit and a permanent injunction was issued against awarding the contract to any firm other than the plaintiff. On October 23, 1989, the DOE filed a notice of appeal. Because of changing requirements and present needs, the DOE is reexamining the need for an $\mathrm{M} \& \mathrm{O}$ contractor.

\subsection{Management-system improvements}

The OCRWM is working to implement a number of improvements in management systems. The most important are changes in the Program Management System, the establishment of a quality-assurance program, and the establishment of configuration management and formal change control over the technical, cost, and schedule baselines.

\subsubsection{Program Management System}

The OCRWM has recently completed a number of improvements to the Program Management System, which consists of the baselines, management plans, policies, procedures, systems, and processes used in managing the program. The Program Management System Manual was revised to incorporate quality assurance into program activities, to effect necessary functional realignments, and to strengthen program direction and control functions. Near-term schedules have been developed for preparation or revision of the various plans and other documents that guide the management of various program functions.

\subsubsection{Quality-assurance program}

A quality-assurance program that meets the requirements of the Nuclear Regulatory Commission has been established. Much effort this year has been devoted to the preparation and issuance of quality-assurance procedures, the training of DOE 
and contractor staff, and qualification audits performed to determine ability to implement the required procedures. As a result, more than 1,000 persons working for eight major program participants have received the required training and are now working under an NRC-accepted program. When the remaining qualification audits are completed in August 1990, a quality-assurance program that has been fully qualified and approved by the NRC will be in place.

\subsubsection{Establishment of baselines}

The technical, cost, and schedule baselines are being established to define the criteria and objectives against which program performance and progress can be measured, thus facilitating effective program control. All reporting and performance measurement will be ultimately tied to the baselines. When potential impacts on the baselines are detected, a corrective action process will be initiated to remove or mitigate the problem. Alternatively, if the problem cannot be removed, the baseline will be modified to the extent necessary. However, any changes in the baselines can be effected only through a formal change-control procedure that involves a systematic review by the appropriate level of management to ensure that all primary and secondary effects of proposed changes are identified and weighed in the decisionmaking process.

The technical baseline, which is currently under revision, includes the functional and technical requirements at the program level. These requirements are being put into final form for issuance over the next several months. This will lead to the development of specifications and designs for system elements and subsystems, evaluations of the specifications and designs against the requirements, and the refinement of the requirements.

The reference program schedule is being formally baselined. This represents the first formal modification of the program schedule baseline since mid-1987. In the spring of 1990, the OCRWM will finalize a cost baseline to accompany the schedule baseline. 


\subsection{Development of a realistic schedule}

\subsubsection{Background}

The Nuclear Waste Policy Act of 1982 required the DOE to begin taking title to spent fuel and high-level waste after the start of repository operations, which were expected to begin no later than January 31, 1998. The DOE's original plan for waste management was to take title to the spent fuel at reactor sites and ship the fuel to a repository, where the waste would be prepared for disposal and then emplaced underground. However, in the Mission Plan issued in June 1985, the DOE described an improved-performance system that included (if authorized by the Congress) an MRS facility as an integral component. This facility was to receive spent fuel shipped from reactor sites, prepare it for emplacement in the repository, and ship it to the repository in dedicated trains. The facility was also to have a limited amount of storage capacity. The DOE identified a number of advantages for a system with an integral MRS facility and developed a preliminary schedule showing that an MRS facility could start accepting waste in 1996, 2 years ahead of the repository. A proposal to the Congress to construct an MRS facility was completed in 1985 , but the DOE was prevented by litigation from submitting it until 1987.

In January 1987, the DOE proposed, in a Draft Mission Plan amendment, that the start of repository operations be delayed by 5 years, until 2003; this delay was later announced in the Mission Plan Amendment issued in June 1987. The reasons for the schedule extension included the delay incurred through consultation in the statutory siting process for the first repository (i.e., the nomination of five sites as suitable for characterization and the recommendation of three sites for characterization); the recognition from this experience that more time should be provided in the future for consultation and interaction with the States, affected Indian Tribes, and other parties; the recognition, resulting from the extensive technical preparation for the development of site-characterization plans, that the site-selection decision and the preparation of the license application to the Nuclear Regulatory Commission will require more information than previously planned; and the recognition that more time will be needed to gain access to the land needed for site characterization.

\subsubsection{Schedule changes stemming from the Secretary's comprehensive review}

The Secretary's comprehensive program review has included a detailed reevaluation of the overall program schedule--that is, the schedule for the repository, the MRS facility, and the transportation program. This effort consisted of a detailed examination of the duration postulated for each specific activity with emphasis on critical-path, near-critical-path, and other major activities. The results of the schedule 
reevaluation are summarized in Figure 1. A more detailed schedule showing significant milestones up to the submittal of the license application is shown in Attachment 1. The near-term decision milestones on which the overall schedule is based are shown in Attachment 2; these milestones are being baselined, and strict management controls are being instituted to ensure adherence to them.

Schedule for the repository. The program review has led to the development of a realistic schedule that is based on past experience and the detailed information developed for the site characterization plan--information that led to a better understanding of the activities to be conducted during site characterization and how long they are likely to take.

Assumptions. The milestones in the schedule have been defined as rigorously as possible on the basis of current plans and currently available information, but it must be recognized that certain activities are beyond the DOE's control and, conversely, that for certain major long-term milestones the DOE may be able to use alternative strategies designed to accelerate the program. In the case of milestones beyond the DOE's control, reasonable assumptions were used. One such assumption was the date for obtaining the permits necessary for new scientific investigations to begin. It was assumed that these new scientific investigations would begin in January 1991. This date is optimistic because it assumes success in the options the DOE has decided to pursue to gain access to the site (see Section 3).

New focus. For the repository, a cornerstone of the schedule is a new focus on the early evaluation of the suitability of the Yucca Mountain site as suggested by the Edison Electric Institute and the State of Nevada. Instead of beginning site characterization with a total-system approach directed at evaluating the performance of engineered barriers as well as the site and based to a large extent on underground testing, this evaluation will focus first on certain particular features of the site that can be investigated through surface-based testing. The revised schedule recognizes, however, that the duration of the scientific investigations, especially the investigations conducted in the exploratory shafts and the underground testing facility, will be considerably longer than previously expected. As a result, the date for submitting the repository license application to the Nuclear Regulatory Commission is now shown as October 2001, a delay of nearly 7 years from the previously scheduled submittal 


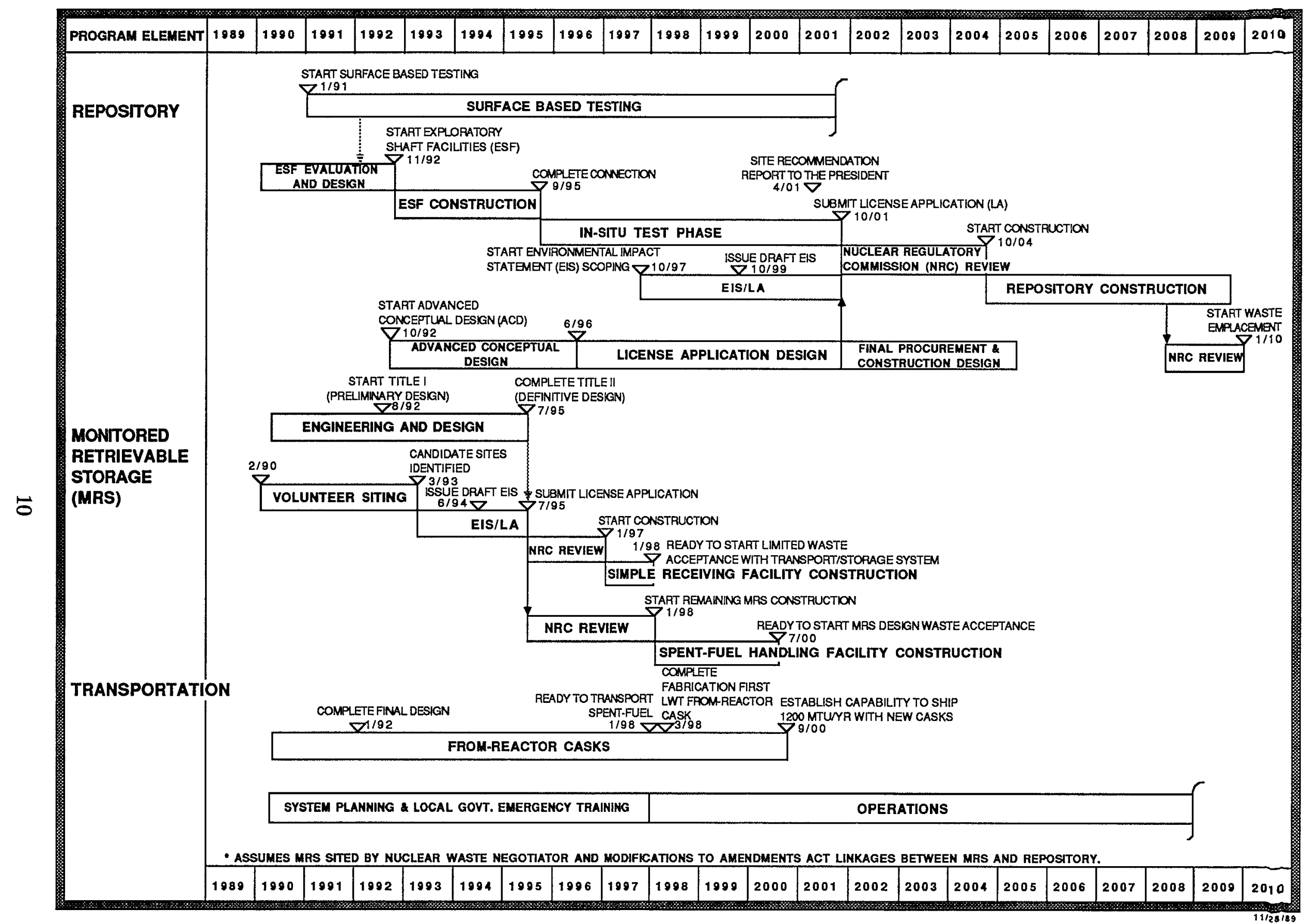

FIGURE 1. REFERENCE SCHEDULE FOR RESTRUCTURED PROGRAM * 
of January 1995, and the start of repository operations is delayed from the year 2003 to 2010.

Initiatives for schedule improvement. While the schedule identifies a substantial delay, the DOE remains committed to seeking ways to improve the schedule while satisfying all technical and regulatory requirements. With this objective in mind, the DOE has initiated a study of alternative strategies for compliance with the NRC requirements in 10 CFR Part 60 for a license application. Each alternative licensing strategy will include the following elements: (1) an approach to determining site suitability, (2) a general plan for licensing, and (3) priorities for testing to support the site-suitability determination. As viable and promising new strategy initiatives emerge from this study, they will be incorporated into the official program plan through the formal change-control procedure.

During the prelicensing phase, the DOE will continue to consult with industry and pursue interactions with the Nuclear Regulatory Commission and the Environmental Protection Agency that are consistent with the regulatory responsibilities and mission of each agency. These interactions are designed to reduce the number of unresolved issues remaining at the time of licensing, which should enhance confidence that the license application can be reviewed in 3 years, as called for in the Nuclear Waste Policy Act. In particular, the DOE will either initiate or encourage the regulatory agencies to begin rulemaking on those issues whose resolution before the licensing phase would enhance the schedule for licensing. For example, the DOE will soon petition the Commission to establish in 10 CFR Part 60 a guideline for the maximum radiation doses that are permissible for accidents occurring during repository operations.

Regarding interactions with the Environmental Protection Agency, the DOE is reviewing the drafts of the revised standards in 40 CFR Part 191, in order to identify any concerns that could undermine DOE's ability to develop a repository or MRS facility. The objective of these interactions during the prelicensing phase is to seek ways of resolving contentious licensing issues before the submittal of the license application.

Schedule for the MRS facility. As indicated in Figure 1, the reference schedule for the MRS facility assumes that (1) a site will be obtained through the efforts of the Nuclear Waste Negotiator and (2) the statutory linkages specified in the Nuclear Waste Policy Amendments Act between the MRS facility and the repository (see Section 4) are modified. Under these assumptions, it is estimated that waste acceptance at an MRS site could begin, on a limited basis, as early as January 1998; a full-capability MRS facility (i.e., a facility that would store spent fuel as necessary and stage spent-fuel shipments to the repository for final disposal), as recommended in the 
DOE's May 1989 statement to the MRS Review Commission, would be available in the year 2000 .

If a site cannot be obtained through the Negotiator but is selected through a DOE-directed siting process and the current statutory linkages are modified, it is estimated that about 2 more years would be added, with the basic MRS facility starting operations in 2002. If the current statutory linkages to the repository are maintained, an additional delay of 5 years would result, with startup estimated at 2007 for the basic MRS facility. As discussed in Section 4, the DOE is pursuing an initiative that would modify these linkages and allow waste acceptance by 1998 .

\subsection{Nuclear Waste Negotiator}

The Secretary is working in close cooperation with the White House to facilitate the appointment of the Nuclear Waste Negotiator as provided for in the Amendments Act. The Negotiator is expected to provide valuable assistance in siting the MRS facility and facilitating the repository program. 


\section{SCIENTIFIC INVESTIGATION OF YUCCA MOUNTAIN}

The DOE is committed to developing a geologic repository for spent fuel and high-level waste through a scientifically based, technically sound, and cost-effective program, and the development of the repository remains the focus of the Civilian Radioactive Waste Management Program. The difficulties facing the repository program therefore received particular attention during the Secretary's comprehensive program review.

The Secretary's review focused on management readiness to proceed with scientific investigations at the Yucca Mountain candidate site, including the implementation of a quality-assurance program that has been reviewed and accepted by the Nuclear Regulatory Commission; the OCRWM's understanding of the magnitude of the effort to be undertaken; and the views of the State of Nevada. As discussed in Section 2.7, the review led to the development of a revised schedule, including nearterm decision milestones, and significant changes in the focus of the near-term program.

\subsection{Site access}

An important factor in the near-term plans for scientific investigations at Yucca Mountain is the unwillingness of the State of Nevada to process the DOE's applications for environmental permits in a manner consistent with the State's legal obligations. For instance, the DOE applied for air-quality permits (needed for surface-disturbing activities)in January 1988 and submitted additional information requested by the State of Nevada in February 1988. Despite State regulations requiring action within 75 days, the Nevada Division of Environmental Protection has yet to issue the DOE an airquality permit or to provide an official denial of the DOE's application. Moreover, on November 1, 1989, the State Attorney General issued an opinion that the State had disapproved the site within the meaning of Section 115 of the Nuclear Waste Policy Act and that State agencies considering environmental permits should disregard DOE's applications.

The DOE is committed to reestablishing confidence in the program. Success in this effort will depend, in particular, on the commencement of the scientific investigations necessary to determine the suitability of Yucca Mountain as the site for the nation's first repository. While cooperation and direct negotiation with the State of Nevada is the preferred approach to expediting scientific investigations, the DOE will pursue all available options to facilitate the timely determination of site suitability. Among them is the option of litigation. 
In order to proceed with necessary characterization efforts, the Secretary has requested that the Department of Justice initiate litigation to declare Nevada's actions invalid.

When the Nuclear Waste Negotiator is appointed, the DOE is prepared to support initiatives developed by the Negotiator that could expedite issuance of the environmental permits necessary to gain access to the Yucca Mountain candidate site. The Negotiator is to seek to enter into negotiations on behalf of the United States with the Governor of any State in which a potential site is located or the governing body of any Indian Tribe on whose reservation a potential site is located.

\subsection{Early evaluation of site suitability}

As already mentioned in Section 2.7 , in its near-term scientific investigations of the Yucca Mountain candidate site, the DOE has decided to focus on surface-based testing aimed specifically at evaluating whether the site has any features that would indicate that it is not suitable as a potential repository site. Therefore, as soon as the permits necessary for surface-based testing are issued, the DOE will begin onsite prototype dry drilling followed by drilling to collect scientific information on the unsaturated zone. The DOE will also collect information on zones of recent faulting, using trenching to better understand the potential for surface offsets in the vicinity of the waste-handling building and the potential for major earthquakes. Also planned are excavations aimed at better understanding the origin of the calcite-silica deposits that have been identified by some program critics as indicators of saturated conditions in the proposed repository horizon. All these scientific investigations will provide early information about the suitability of the site. This approach is in concert with a number of suggestions, particularly from the State of Nevada and the Edison Electric Institute, that scientific investigation activities focus on potentially adverse conditions and that efforts be made to evaluate key suitability issues early in the process.

Because of the emphasis on surface-based testing for specific conditions, the construction of exploratory shafts is delayed until 1992, as shown in Figure 1. This will allow the DOE to carefully reevaluate, in accordance with all applicable qualityassurance and NRC requirements, the locations chosen for the two exploratory shafts, the method chosen (drilling and blasting) for the construction of the shafts, the means of access (ramps or shafts) to the repository horizon, the need for additional exploratory drifts, and the design of the shafts and other components of the exploratory-shaft facility. Requests for the reevaluation of shaft location and design have come from the NRC staff, while the suggestions to reconsider the means of 
access, the shaft-construction method, and the need for additional drifts came from the Nuclear Waste Technical Review Board.

The new focus on surface-based testing is not meant to suggest that underground testing at the proposed repository depth is now deemed less important. On the contrary, as shown in Figure 1, the Secretary's evaluation has led to an extension of the schedule for in-situ testing, in accordance with the commitment to conduct a scientifically based and technically sound program. The Secretary believes that conducting both surface-based and underground tests, combined with continuing evaluation of the data as they are obtained, will allow a cost-effective and timely assessment of the site.

Recognizing that the Yucca Mountain candidate site could be found unsuitable, the DOE will also support the Negotiator in efforts to identify alternative volunteer repository sites.

\subsection{Deferral of major site-specific design activities}

Because of the change in the plans for scientific investigations at the Yucca Mountain candidate site and the extension of the schedule, major activities related to the design of a repository at the Yucca Mountain site and the waste package are being deferred. They will be resumed when more information is available concerning the suitability of the site. This approach will conserve resources and allow the DOE to concentrate efforts on scientific investigations. 


\section{MONITORED RETRIEVABLE STORAGE}

Other highly industrialized countries in which nuclear power plays a prominent role, such as Sweden, Germany, and France, are providing centralized interim storage facilities while pursuing repository-development programs. This has allowed these countries to provide near-term management for the spent fuel and to conduct their repository programs at a pace not dictated by unrealistic waste-acceptance objectives. The DOE believes that a similar approach should be considered in the United States.

\subsection{Statutory provisions for an MRS facility}

The Amendments Act authorizes the DOE to site, construct, and operate an MRS facility subject to the following conditions:

1. The Secretary may not select an MRS site until a repository site is recommended to the President.

2. Any NRC license for an MRS facility is to provide for the following:

a. The construction of the MRS facility cannot begin until the NRC has issued a license for the construction of the repository.

b. MRS construction (or waste acceptance) is prohibited if the construction of the repository ceases or if the repository license is revoked.

c. No more than 10,000 metric tons of heavy metal (MTHM) may be stored at the MRS facility until the repository begins receiving waste.

d. No more than 15,000 MTHM may be stored at the MRS site at any one time thereafter.

\subsection{MRS Review Commission}

The Amendments Act also created an independent MRS Review Commission that was to report to the Congress on the need for an MRS facility. In its report of November 1, 1989, the MRS Review Commission found that "cumulatively the advantages of an MRS would justify the building of an MRS if: (1) there were no linkages between the MRS and the repository; (2) the MRS could be constructed at an 
early date; and (3) the opening of the repository were delayed considerably beyond its presently scheduled date of operation."

The MRS Review Commission recommended that the Congress authorize the construction of a Federal Emergency Storage facility with a capacity limit of 2,000 metric tons of uranium; authorize the construction of a User-Funded Interim Storage facility with a capacity limit of 5,000 metric tons of uranium; and reconsider the need for additional interim storage in the year 2000. Thus, the DOE and the MRS Review Commission agree as to the necessity for a facility that would provide storage before permanent geologic disposal, but they differ on the storage capacity required and the appropriate funding mechanism.

\subsection{DOE's position on the MRS facility}

The DOE testified to the MRS Commission on May 25, 1989, that it supports the development of an MRS facility as an integral part of the waste-management system because an integrated MRS facility is critical to achieving the goal of early and timely acceptance of spent fuel and because it would allow the DOE to better meet other strategic objectives, such as timely disposal, schedule confidence, and system flexibility. Though it considered a waste-management system with an MRS facility subject to the current statutory linkages superior to a system without an MRS facility, the DOE stated that a revision of the linkages and the statutory storage-capacity limit would allow the advantages of an MRS facility to be more fully realized. The DOE also expressed preference for an MRS facility sited through the efforts of the Negotiator, especially if these siting negotiations lead to modified linkages.

Schedule delays and the uncertainties inherent in the development of a geologic repository underscore the importance of an integrated MRS facility to the wastemanagement system. Such a facility could start operations as early as 1998 and is a key component in the DOE's strategy for building confidence in the program.

An integrated MRS facility would enhance confidence in the program for the following reasons: First, it can be developed rapidly because it will make maximum use of technologies that have been proved and because it has fewer licensing uncertainties than a geologic repository. Second, an MRS facility would demonstrate that the Federal Government is using all available means to ensure timely acceptance of spent fuel for disposal. Third, an MRS facility would also show that the Federal Government is able to safely accept, transport, and handle spent fuel early in the program. Fourth, an integrated MRS facility will allow an orderly transfer of spent fuel from reactor sites to the Federal waste-management system independent of the ability to emplace' fuel in the repository. 


\subsection{DOE's initiatives for the MRS facility}

The DOE believes that the need to build confidence in the program and its schedule requires that the current statutory linkages be modified to facilitate the staged development of an integral MRS facility. Accordingly, the DOE is pursuing the courses of action outlined below. The DOE believes that these actions are consistent with the conclusions reached by the MRS Review Commission as documented in their report.

\section{Interactions with the Congress to revise linkages}

The DOE will work with the Congress to modify current linkages and constraints on the MRS facility, thereby allowing the MRS facility to start operation significantly earlier than the repository and increasing the amount of spent fuel that can be temporarily stored at the MRS site. The Secretary believes that these modifications will build confidence in the program by allowing the MRS benefits to be realized earlier in the development of the waste-management system.

\section{Support for the Negotiator}

The Amendments Act prohibits the selection of an MRS site through a DOE-directed site-survey process until the repository site is formally selected. However, the Amendments Act allows for expedited siting to proceed via a Negotiator, who may negotiate a proposed agreement with a State or Indian Tribe that offers a technically qualified site on reasonable terms.

How rapidly a negotiated MRS facility can come on line and how much spent fuel it can store will depend on the negotiated agreement, which must be approved by Congress. In principle, a negotiated agreement represents an effective way of developing the facility and should allow the MRS advantages to be more fully realized. Moreover, a negotiated site would avoid the institutional issues associated with a DOE-directed siting process.

The Negotiator will receive the full cooperation and assistance of the DOE to respond quickly to offers from potential volunteers and to ensure that the program can be adapted, with minimum cost and delay, to the approval by the Congress of a negotiated site. Under the Amendments Act, financial assistance for assessing the feasibility of siting an MRS facility is available to a State or Indian Tribe that is a potential host.

\section{DOE-directed siting program}

The DOE would prefer that the MRS facility be located at a volunteer site under a proposal developed by the Negotiator and approved by the Congress. However, 
because there is no assurance that the Negotiator will be successful and because of the importance of an integrated MRS facility to the waste-management system, the DOE must be prepared to proceed with MRS siting. The DOE will begin planning such a siting activity and be prepared for its implementation if necessary. 


\section{CONCLUSIONS}

The Secretary has recently completed an extensive review of the program and has concluded that it cannot be effectively executed in its current form. However, it should be possible to develop a technically sound integrated waste-management system with a repository for permanent disposal if the DOE (1) continues to implement management improvements; (2) pursues an orderly program of scientific investigations that is not driven by unrealistic scheduling demands; and (3) establishes an MRS facility with more flexible linkages to the repository to allow early acceptance of spent fuel. The program will be restructured in accordance with this approach.

The DOE is confident that the actions taken and those proposed will ensure the development of an environmentally safe and efficient nuclear waste-disposal program. Working with the Congress and other interested parties, the program outlined herein will result in development of a radioactive-waste disposal system as envisioned in the law. 


\section{ACRONYMS AND ABBREVIATIONS USED IN ATTACHMENTS}

\begin{tabular}{|c|c|}
\hline BA & Biological assessment \\
\hline BLM & Bureau of Land Management \\
\hline DCP & Document change proposal \\
\hline DEIS & Draft environmental impact statement \\
\hline Doc. & Document \\
\hline DOE & Department of Energy \\
\hline DOJ & Department of Justice \\
\hline EA & Environmental assessment \\
\hline EIS & Environmental impact statement \\
\hline ESAAB & Energy Systems Acquisition Advisory Board \\
\hline ESF & Exploratory-shaft facility \\
\hline FEIS & Final environmental impact statement \\
\hline FWS & Fish and Wildlife Service \\
\hline GC & General Counsel \\
\hline HQ & Headquarters (DOE) \\
\hline LA & License application \\
\hline LAD & License-application design \\
\hline LWT & Legal weight \\
\hline MA & Office of Assistant Secretary for Management and Administration \\
\hline MA-1 & Assistant Secretary for Management and Administration \\
\hline MOA & Memorandum of agreement \\
\hline MRS & Monitored retrievable storage \\
\hline MTU & Metric tons of uranium \\
\hline NRC & Nuclear Regulatory Commission \\
\hline NV & Nevada Operations Office, DOE \\
\hline OCRWM & Office of Civilian Radioactive Waste Management \\
\hline PCCB & Program Change Control Board \\
\hline PDS & Project Decision Schedule \\
\hline PECCB & Program Elements Change Control Board \\
\hline PMS & Program Management System \\
\hline Repos. & Repository \\
\hline Rev. & Revision \\
\hline ROD & Record of decision \\
\hline RW-1 & Director, Office of Civilian Radioactive Waste Management \\
\hline S-1 & Secretary of Energy \\
\hline SBT & Surface-based testing \\
\hline SEMP & Systems Engineering Management Plan \\
\hline SFHB & Spent-fuel handling building \\
\hline SRR & Site Recommendation Report \\
\hline
\end{tabular}


TRB

WMS

WP
Nuclear Waste Technical Review Board

Waste management system

Waste package 